\title{
The Threat from Within across Empires: Strikes, Labor Migration, and Violence in Central Europe, 1900-1914
}

\author{
Amerigo Caruso and Claire Morelon
}

\begin{abstract}
The decade before the First World War saw a heightened level of social and political conflicts throughout Germany and Austria-Hungary. Strikes in pre-1914 central Europe have largely been examined as part of the development of the workers' movement, but much less often from the perspective of the employers and government elites. Their strategies to counteract "strike terrorism" included hiring replacement workers through private strikebreaking agents, who provided a variety of services such as recruitment, transportation, housing, and providing "willing workers" with weapons for their self-defense. The discourses around "strike terrorism," and the repressive strategies to counter it, are a lens through which we can look afresh at some of the most crucial issues in the history of central European empires in the prewar years, namely the structure of violence embedded in social conflicts, migration, growing political antagonism, and fears surrounding social democracy. This article analyzes the public debate around the protection of "willing workers" as well as concrete episodes of antilabor violence in a transnational framework. It offers a reassessment of social conflicts in the period following the 1905 social mobilizations in central Europe, and it explores the circulation of antilabor measures between Germany and Austria-Hungary, their radicalizing impact, and their connections with labor migration patterns.
\end{abstract}

$\mathrm{I}$ N August 1904, in the midst of a carpenters' labor dispute in Bremen, an agent came to Prague searching for men to replace the strikers. When he arrived in the city, he went straight to the meeting place of the local carpenters and in a short time managed to recruit 150 men. At the train station, he plied them with free food, drink, and tobacco. Once on the way to Germany, however, the agent instructed the men to seize a hard object to protect themselves from the strikers upon arrival in Bremen. The workers then immediately stepped out of the train and beat up the agent, who was left lying on the ground. "One more such successful beating and no one will come from Germany to Bohemia to hire strikebreakers," concluded triumphantly the Czech social democratic newspaper Nová Doba. ${ }^{1}$ Yet, this wish was to remain unfulfilled, as agents from Germany continued to cross the border into neighboring Austria-Hungary in increasing numbers during the following decade. In a context of manpower shortage, growing labor mobility, and heightened

Research for this article was supported by the European Research Council (ERC) under the European Union's Horizon 2020 research and innovation program (G. A. 677199-ERCStG2015 “The Dark Side of the Belle Époque. Political Violence and Armed Associations before the First World War"). The authors would like to thank Giulia Albanese, Nicola Camilleri, and Matteo Millan for their comments on a previous version of this article, as well as the anonymous reviewers for their useful suggestions.

${ }^{1}$ Nová Doba, August 13, 1904, 4. 
industrial disputes, the employers' demand for replacement workers broadened the scope of recruitment areas and increased recourse to strikebreaking agents. This, in turn, fueled the physical and discursive violence around strikes, which had already led to the death of six workers through strikebreakers or their agents in Germany since 1906 and culminated in the killing of a unionized worker in Bohemia by a strikebreaking agent from Berlin in 1914.

With increased unionization among workers and the potential disruption of social hierarchies it entailed, strikes became a serious concern in turn-of-the-century central Europe. In Imperial Germany, especially after the political crisis that followed the Social Democratic Party's (SPD's) election victory in 1903, strikes and mass demonstrations in support of universal suffrage were perceived as a prime threat to the social order. ${ }^{2}$ Similarly, while AustriaHungary has long been considered to have been in permanent crisis due to mounting ethnic tensions, issues associated with the rise of social democracy and the push for democratization played a key role in domestic policy before and after the suffrage reform of $1907 .{ }^{3}$ The wave of strikes and political protests that took place in many German and Austro-Hungarian cities in the wake of the Russian Revolution in 1905 gave renewed urgency to antilabor mobilization. ${ }^{4}$ By then, the very repressive methods used to tackle early strike waves in the 1870 s and 1880 s were considered as less legitimate in an era of consolidated constitutional rule. In Germany, after the granting of coalition rights in 1869 (Gewerbeordnung), major eruptions of strike activity had produced the first efforts of employers to delegitimize labor disputes as an economic and even moral "calamity." ${ }^{5}$ Industrial magnates and their newspapers had loudly demanded new limitations on coalition freedom, and already saw the protection of strikebreakers as a key aspect of counterstrike strategies. This early antistrike mobilization culminated in the elaboration of repressive measures against the "abuse" of coalition freedom, which were rejected by the Reichstag in 1874. In Habsburg Austria, where coalition rights were introduced in 1870, the early labor movements of the 1870s and 1880s were characterized by violent methods and compared to anarchistic attacks. Strikes had been heavily

\footnotetext{
${ }^{2}$ See Jens-Uwe Guettel, "Reform, Revolution, and the 'Original Catastrophe': Political Change in Prussia and Germany on the Eve of the First World War," The Journal of Modern History 91, no. 2 (2019): 311-40. On antisocialism in general, see James Retallack, Red Saxony: Election Battles and the Spectre of Democracy in Germany, 1860-1918 (Oxford: Oxford University Press, 2017).

${ }^{3}$ Janek Wasserman has recently emphasized the antisocialism of prewar Austrian economists; their project to make the world safer for economic interests responded to the growth of a perceived threat to the status quo; see Janek Wasserman, The Marginal Revolutionaries: How Austrian Economists Fought the War of Ideas (New Haven: Yale University Press, 2019). On protests for universal manhood suffrage, see Jakub S. Beneš, Workers and Nationalism: Czech and German Social Democracy in Habsburg Austria, 1890-1918 (Oxford: Oxford University Press, 2016); on 1907, see John W. Boyer, "Power, Partisanship, and the Grid of Democratic Politics: 1907 as the Pivot Point of Modern Austrian History," Austrian History Yearbook 44, no. 4 (2013): 148-74.

${ }^{4}$ In both countries, the last decade before 1914 corresponded to a rise in the number of strikes and labor conflicts: in Austria-Hungary, from approximately 300 labor disputes in 1900 to an average of 750 per year between 1905 and 1913; in Germany, from an average of almost 1,300 strikes per year around 1900 to more than 2,500 between 1905 and 1913. Brian R. Mitchell, "Labour Force," in European Historical Statistics 1750-1970, ed. Brian R. Mitchell (London: Columbia University Press, 1975), 151-96, esp. 173-74.

${ }^{5}$ See Lothar Machtan, “'Giebt es kein Preservativ, um diese wirthschaftliche Cholera uns vom Halse zu halten?' Unternehmer, bürgerliche Öffentlichkeit und preußische Regierung gegenüber der ersten großen Streikwelle in Deutschland (1869-1874)," in Politischer Streik, ed. Heinz-Gerhard Haupt (Frankfurt: Europäische Verlagsanstalt), 54-100.
} 
repressed with the imposition of the state of exception on several cities for longer periods and condemnations for treason and subversion. ${ }^{6}$

Around 1900, however, the supraregional organization on both employers' and workers' sides, the growth of strike activity, and a much heightened labor mobility created new conditions for the development of counterstrike strategies. Freedom of labor and the threat to national security posed by internal unrest became increasingly important issues, with the discourse on both sides becoming radicalized. Employers and conservatives framed their discourse in terms of defending the freedom to work against "strike terrorism," while social democrats accused strikebreaking agents of turning workers into "slaves." In reframing strikebreaking - the recruitment of replacement workers during a strike-as a question of freedom, with slave handlers on the one hand, "strike terrorism" on the other, both sides claimed to be protecting workers.

After the turn of the century, the issue of strikebreaking became a media battle of information and a new arena for ideological antagonism. As this article will show, the heightened debates on strikes and the rise of professional strikebreaking were closely linked with crucial aspects of the history of social change, labor mobility, political polarization, and violence before the First World War. ${ }^{7}$ This article also revises current conceptions of political violence in early twentieth-century central Europe, which emphasize the role of military defeat and of the Bolshevik revolution in the development of counterrevolutionary forces, by showing that these tensions had already reached a critical stage before the war. ${ }^{8}$

Debates around the pressures exerted by the social democrats and the solutions to them were fought on a transnational scale. Employers used international networks to oppose organized labor and mobilize against "strike terrorism." They sourced replacement workers across borders and also cooperated with other employers abroad through the sharing of ideas and practices. While these exchanges took place all over Europe, they were particularly developed in the Hohenzollern and Habsburg empires. Employers in German-speaking central Europe faced some of the most highly organized unions on the continent, while differences in pay meant that German agents often sought replacement workers in the Habsburg monarchy. Interconnections between employers and their strikebreaking networks mostly remained translocal, just as worker solidarity grew internationally, yet frequently remained regionally embedded (with neighboring countries making greater contributions to strike funds). ${ }^{9}$ The border zones in southern Germany, Bohemia, Silesia, Upper Austria, Salzburg, and West Galicia emerged as recruitment sites, although agents sometimes traveled

\footnotetext{
${ }^{6}$ See Herbert Steiner, Die Arbeiterbewegung Österreichs 1867-1889 (Vienna: Europa-Verlag, 1964).

${ }^{7}$ While violence between strikers and strikebreakers in North America has received huge scholarly attention, the spread of violent strikebreaking in Europe has been largely overlooked. See, among many works, Stephen H. Norwood, Strikebreaking and Intimidation: Mercenaries and Masculinity in Twentieth-Century America (Chapel Hill: University of North Carolina Press, 2003); Gunther Peck, Reinventing Free Labor: Padrones and Immigrant Workers in the North American West, 1880-1930 (Cambridge: Cambridge University Press, 2000).

${ }^{8}$ Robert Gerwarth underlines that the criminalization and dehumanization of both internal and external enemies had its roots before 1914 but only came to full expression after 1917; see Robert Gerwarth, The Vanquished: Why the First World War Failed to End, 1917- 1923 (London: Allen Lane, 2016), conclusion.

${ }^{9}$ On international workers' solidarity, see Nicolas Delalande, La Lutte et l'entraide: l'âge des solidarités ouvrières (Paris: Seuil, 2019); on translocal entanglements, see Christian Koller, "Local Strikes as Transnational Events: Migration, Donations, and Organizational Cooperation in the Context of Strikes in Switzerland (1860-1914)," Labour History Review 74, no. 3 (2009): 305-18.
} 
much farther afield. ${ }^{10}$ Furthermore, the flow was not always unidirectional given German workers were sometimes brought to Austria as strikebreakers as well. Switzerland and northern Italy also formed part of this central European space of antilabor mobilization, with Swiss employers highly engaged in discussions with their German and Austrian counterparts while Italy often served as a labor reservoir. The picture emerging is that of a highly porous central European space where both practices and people intensely circulated.

The new interest in empire is fostered by a conceptual turn toward transnational history. ${ }^{11}$ Although the number of studies on individual empires has increased exponentially, this has not been the case for comparative studies and translocal imperial connections. This article adopts a transnational rather than comparative approach to fill this research gap, ${ }^{12}$ which is particularly evident with regard to the years leading up to the "crisis of empire" after 1917. ${ }^{13}$ Without proposing a new supra-imperial framework, this approach focused on concrete interactions enables us to examine some of the center/periphery dynamics between and within these two imperial spaces in the relations of border regions to industrial centers. ${ }^{14}$ The economic and informational disparities in regional peripheries, as well as language diversity, made these imbalances easily exploitable. ${ }^{15}$

In the first section, we examine how militant antisocialism, antistrike reactions, and social democratic partisan journalism contributed to radicalizing the political language within the context of the media revolution and emerging mass politics before $1914 .{ }^{16}$ Although this first section focuses on the discourse of "strike terrorism" that played out on a transnational scale, the second section explores the social reality in which the narrative of "strike terrorism" found fertile soil, focusing in particular on the link between commercialized strikebreaking

\footnotetext{
${ }^{10}$ On the Bohemian Saxon border, see Caitlin Murdock, Changing Places: Society, Culture, and Territory in the Saxon-Bohemian Borderlands, 1870-1946 (Ann Arbor: University of Michigan Press, 2010); Katrin Lehnert, Die Un-Ordnung der Grenze. Mobiler Alltag zwischen Sachsen und Böhmen und die Produktion von Migration im 19. Jahrhundert (Leipzig: Universitätsverlag, 2017).

${ }^{11}$ Ulrike von Hirschhausen and Jörn Leonhard, "Beyond Rise, Decline and Fall: Comparing Multiethnic Empires in the Long Nineteenth Century," in Comparing Empires: Encounters and Transfers in the Long Nineteenth Century, ed. Jörn Leonhard (Göttingen: Vandenhoeck \& Ruprecht, 2011), 9-34, esp. 14.

${ }^{12}$ For a comparison of labor disputes in Germany and Austria-Hungary, see Marina Cattaruzza, “'Organisierter Konflikt' und 'Direkte Aktion.' Zwei Formen des Arbeitskampfes am Beispiel der Werftarbeiterstreiks in Hamburg und Triest (1880-1914)," Archiv für Sozialgeschichte 20 (1980): 325-55; for a study of a border region, see Murdock, Changing Places.

${ }^{13}$ See Robert Gerwarth and James E. Kitchen, "Transnational Approaches to the 'Crisis of Empire' after 1918," Journal of Modern European History 13, no. 2 (2015): 173-82.

${ }^{14}$ Our analysis of both empires does not pretend to make a claim on the imperial nature of the German Kaiserreich or Austria-Hungary. On these debates, see, for Austria-Hungary, Pieter Judson, "L'AutricheHongrie était-elle un empire?” Annales. Histoire, Sciences Sociales, 63, no. 3 (2008): 563-96. For Germany, Philipp Ther, "Deutsche Geschichte als imperiale Geschichte. Polen, slawophone Minderheiten und das Kaiserreich als kontinentales Empire," in Das Kaiserreich transnational: Deutschland in der Welt 1871-1914, ed. Sebastian Conrad and Jürgen Osterhammel (Göttingen: Vandenhoeck \& Ruprecht, 2006), 129-47.

${ }^{15}$ On the exploitation of natural resources, see Jawad Daheur, "La Galicie autrichienne: 'colonie du bois' de l'Empire allemand? (1890-1914)," Revue d'Allemagne et des pays de langue allemande 48, no. 1 (2016): 25-42.

${ }^{16}$ See Frank Bösch, Mass Media and Historical Change: Germany in International Perspective, 1400 to the Present (New York: Berghahn Books, 2015); Alex Hall, Scandal, Sensation and Social Democracy: The SPD Press and Wilhelmine Germany 1890-1914 (Cambridge: Cambridge University Press, 1977); on the Austrian press, see Gabriele Melischek and Josef Seethaler, "Presse und Modernisierung in der Habsburgermonarchie," in Die Habsburgermonarchie, vol. VIII/2, ed. Helmut Rumpler and Peter Urbanitsch (Vienna: Austrian Academy of Sciences, 2006), 1535-714.
} 
and the emergence of an integrated European labor migration space. Finally, the third section moves forward to analyze the impact of transnationally active bands of strikebreakers on the rise of a new dimension in violence in the decade before the outbreak of the First World War.

\section{Mobilizing Against "Strike Terrorism"}

In August 1898, bricklayers went on strike in Potsdam, residence of the Prussian kings since the late seventeenth century. Striking workers organized picket lines outside the railway station, effectively preventing strikebreakers from entering the city. ${ }^{17}$ The labor dispute took place only a few kilometers from the royal palace and triggered a furious reaction from the kaiser, who decided to address the issue of "strike terrorism" during the next Crown Council meeting. Wilhelm II discussed with his ministers the risk that the social democrats might control almost the entire working class in the near future. He argued that the only way to preserve law and order in the German empire was to revive Bismarck's old strategy of "blood and iron" (this time in the area of domestic policy). ${ }^{18}$ During a Crown Council meeting in October 1898, a few months after the bricklayers' strike in Potsdam, the kaiser and his conservative ministers proposed a penitentiary bill to penalize picketing (Zuchthausvorlage).

German employers, such as steel magnate Carl Ferdinand von Stumm, a personal friend of the kaiser, depicted with renewed impetus the labor movement as a major threat to national cohesion. Once again, after the first unsuccessful efforts to tackle "strike terrorism" in the early 1870s, they proposed restricting the freedom of coalition in order to protect "willing workers." ${ }^{19}$ In November 1898, Wilhelm II and Chancellor Hohenlohe-Schillingsfürst agreed on the urgent need to contain the alleged "physical and psychological violence" against strikebreakers. ${ }^{20}$ They were confident that the projected penitentiary bill to penalize picketing would "drastically limit strike terrorism." ${ }^{21}$ Wilhelm II, who was on his way to his second ostentatious state visit to the Ottoman Empire, still managed to take an active part in the process of drafting the overtly repressive text. ${ }^{22}$ Eventually, the draft was presented to the Reichstag but again defeated by the parliamentary opposition.

This example reveals the importance of social conflicts in the minds of the government elites and shows how the notion of strike terrorism permeated German society. Verbal escalation and an emotionally charged, ideologically polarized public discourse became part of the political culture both in Germany and in neighboring Austria-Hungary. The rise of mass social movements and the birth of a modern media society form the background for sensationalized debates on violence and security around 1900, which publicized not only "strike terrorism" but also criminality, catastrophic events, and accidents. ${ }^{23}$ The violence

\footnotetext{
${ }^{17}$ Vorwärts, August 13, 1898, 3.

${ }^{18}$ Hartwin Spenkuch, ed., Die Protokolle des Preußischen Staatsministeriums 1817-1934/38, vol. 8/I, 21. März 1890 bis 9. Oktober 1900 (Hildesheim: Olms-Weidmann, 2003), 322.

${ }^{19}$ Frankfurter Zeitung, January 17, 1898.

${ }^{20}$ Wilfried Rudloff, ed., Quellensammlung zur Geschichte der deutschen Sozialpolitik 1867 bis 1914, Abt. III, Ausbau und Differenzierung der Sozialpolitik seit Beginn des Neuen Kurses (1890-1904), vol. 4, Arbeiterrecht (Darmstadt: WBG, 2011), 299.

${ }^{21}$ Rudloff, Quellensammlung zur Geschichte der deutschen Sozialpolitik 1867 bis 1914, 302.

${ }^{22}$ Rudloff, Quellensammlung zur Geschichte der deutschen Sozialpolitik 1867 bis 1914, 303-05.

${ }^{23}$ See Roger Cooter, "The Moment of the Accident: Culture, Militarism and Modernity in LateVictorian Britain," in Accidents in History: Injuries, Fatalities and Social Relations, ed. Roger Cooter and Bill Luckin (Amsterdam: Brill, 1997), 107-57.
} 
that sometimes took place during strikes found amplified resonance in the conservative press. This discourse relied on negative representations of workers as unruly and prone to criminality, and invited sympathy for the replacement workers. ${ }^{24}$ For example, reporting on the trial of workers who had attacked strikebreakers outside a Graz bicycle factory in 1908, the Grazer Volksblatt detailed all the insults and blows received by the replacement workers on their way home and depicted them as "the first victims of social democratic baiting." 25 Heightened social tensions and the ascent of social democracy gave rise to a counter-discourse that deplored the pressure put on workers to join the strikes. Employers and the press portrayed the verbal and physical coercion of nonstrikers, and even the mere presence of picket lines, as a form of terrorism. The notion of strike terrorism implied that those workers who did not join the strikes ("strikebreakers" in the language of the social democrats, or "willing workers" for the opposing side) were victims of a violent intimidation campaign and in need of protection. ${ }^{26}$ This term linked the fears generated by strikes to the "moral panic" stemming from the political assassinations and anarchism that gripped Europe in the last decades of the nineteenth century. By labeling strikers as terrorists, employers and the press equated their actions with the spectacular bombings and assassinations of the period, and integrated them into the broader picture of threats to the established order. ${ }^{27}$ The framing of industrial unrest and mass demonstrations as a threat to national security made the labor movement an "object of securitization" for conservative circles. ${ }^{28}$ Unionization and strikes were not simply conceived as local legitimate disputes but as urgent security concerns. This process of "securitization" exacerbated social conflicts and justified conservative demands for extraordinary countermeasures.

The strike terrorism narrative played a crucial role in transforming antisocialist fears and political antagonism into social reality. It took on a particular degree of intensity and perceived urgency in Imperial Germany and Habsburg Austria, where the dynamics of social change, unionization, and modernization were more concentrated within a short period of time and more radical than elsewhere in Europe. Employers in Austria saw the use of strikes and the "unrelenting coercion of willing workers" as a sign of the importation of social democratic methods from Germany to Austrian soil. According to them, the consequences were even more detrimental there and to be combated more forcefully as Austria's industrial development was more fragile. ${ }^{29}$ Another reason for the heightened discourse of strike terrorism was the highly effective antilabor campaign disseminated by

\footnotetext{
${ }^{24}$ On negative representations, see for Vienna, Wolfgang Maderthaner, Unruly Masses: The Other Side of Fin-de-Siècle Vienna (Oxford: Berghahn, 2008). For Paris, see Dominique Kalifa, Les bas-fonds: histoire d'un imaginaire (Paris: Seuil, 2013).

${ }^{25}$ Grazer Volksblatt, February 16, 1908, 12.

${ }^{26}$ See, for example, Rudolf Lebius, Gelbe Gedanken (Berlin: Reformverlag Der Bund, 1908), 6.

${ }^{27} \mathrm{On}$ anarchist terrorism and assassinations against political leaders around 1900, see Richard Jensen, The Battle Against Anarchist Terrorism: An International History (1878-1934) (Cambridge: Cambridge University Press, 2013); Heinz-Gerhard Haupt, Den Staat herausfordern. Attentate in Europa im späten 19. Jahrhundert (Frankfurt: Campus, 2019).

${ }^{28}$ The concept of "securitization" is developed with the examples of Germany and England in Christine Krüger and Friedrich Lenger, "'A Question of Power and War': Social Conflict in Hamburg and London in the Late Nineteenth Century," in Conceptualizing Power in Dynamics of Securitization: Beyond State and International System, ed. Regina Kreide and Andreas Langenohl (Baden-Baden: Nomos, 2019), 239-63, esp. 249.

${ }^{29}$ See a memorandum from the Central Union of Builders in Lower Austria to the Interior Ministry, May 7, 1906, Österreichisches Staatsarchiv (Austrian State Archives, hereafter ÖStA), Allgemeines Verwaltungsarchiv (hereafter AVA), Ministerium des Innern (hereafter MdI), Präsidiale (hereafter Präs), K1990, sig. 20/9, no. 4069/06.
} 
Austrian and German employers and, in Germany, especially, by right-wing pressure groups such as the Imperial League against Social Democracy (1904). In the central European empires, the mobilization against the strike threat had a broad impact, not only shaping the political discourse, but also prompting countermeasures from the "loyal classes."

The narrative of strike terrorism was not, however, unique to the conservative monarchies of central Europe. In early twentieth-century France, the debate on the freedom to work versus the freedom to strike was also an important part of the discussions on strikes. In the 1890s and the first decade of the twentieth century, several attempts were made to reform those articles of the French Penal Code restricting coalition, which were often used to limit picketing. ${ }^{30}$ French courts could use the penal code to penalize workers who prevented others from working (more extreme legislation was in place in Belgium, where picketing was entirely forbidden). ${ }^{31}$ Widespread fears of strike violence and concerns for the safety of nonstriking workers also existed in French society, and the notion of "terreur syndicale" (the equivalent of Streikterrorismus) surfaced in the press. ${ }^{32}$ However, the strategies adopted by employers against strikes remained less systematic in France. ${ }^{33}$ In Great Britain, as early as the 1890s and increasingly after the turn of the century, the "political terrorism" of organized labor had been stigmatized by conservative newspapers, such as the Daily Mail, and prominent "free labor" organizations, such as the National Free Labour Association (1893) led by William Collison, self-proclaimed "king of the blacklegs." ${ }^{34}$ However, hostile legal decisions came to an end under increased parliamentary pressure from the Labour Party with the passing of the Trade Disputes Act in 1906.

The notion of "terrorism" applied to labor disputes circulated transnationally and pervaded political discussions on strikes around 1900. The heightened language was not limited to fringe publications, but was instead widely used and reflected growing concerns. Supported by employers' associations and by the Imperial League against Social Democracy, a large number of publications opposed to strike terrorism and in favor of better protection of willing workers circulated in Germany in the decade before the beginning of the First World War. ${ }^{35}$ In 1909, the league published a propaganda leaflet listing hundreds of these alleged "cases of terrorism" (Terrorismusfälle). ${ }^{36}$ It also advised victims of "terrorism" on how best

\footnotetext{
${ }^{30}$ See, for example, Eugène d'Eichthal, La liberté individuelle du travail et les menaces du législateur (Paris: F. Alcan, 1908).

${ }^{31}$ Falcoz, "Les entraves à la liberté du travail" (PhD diss., Université de Paris, 1911), 68.

${ }^{32}$ One of the most famous examples is the case of union leader Jules Durand, who was accused of having called for the murder of a nonstriking worker during a union meeting and was wrongfully convicted in 1910; see Laurence Montel, "Autour de l'affaire: les policiers face aux grèves dans le port du Havre à la fin des années 1900," in Jules Durand, un crime social et judiciaire, ed. John Barzman and Jean-Pierre Castelain (Paris: L'Harmattan, 2015), 67-83.

${ }^{33}$ Peter N. Stearns, "Against the Strike Threat: Employer Policy toward Labor Agitation in France, 1900-1914," The Journal of Modern History 40, no. 4 (1968): 474-500.

${ }^{34}$ Arthur McIvor, Organised Capital: Employers' Associations and Industrial Relations in Northern England 1880-1939 (Cambridge: Cambridge University Press, 1996), 93.

${ }^{35}$ See, for example, Konrad Engel, Zum Ausstande der Bergarbeiter im Ruhrbezirk (Berlin: Springer, 1905); Bernhard Blüher, Der Schutz der Arbeitswilligen (Dresden: Veröffentlichungen des Verbands Sächsischer Industriellen, 1912); Hoff and Henrich, Berichte über den Schutz der Arbeitswilligen, erstattet auf der Mitgliederversammlung der Vereinigung der Deutschen Arbeitgeberverbände am 13. März in Berlin (Berlin: Bahr, 1914).

${ }^{36}$ Sozialdemokratischer Terrorismus. Kritische Betrachtungen nebst einer Auswahl gerichtlich abgeurteilter Terrorismusfälle (Berlin: Reichsverband gegen die Sozialdemokratie, 1909).
} 
to resist. In the same period, German "yellow" newspapers mushroomed and systematically denounced episodes of "red terrorism." 37

In Austria, too, employers saw the increased organization of workers as a form of terrorism holding them hostage. The Union of Industrialists reported several cases of workers threatening to strike if nonunionized workers were hired and viewed it as a blatant example of the "terrorism" exercised by workers' organizations. ${ }^{38}$ The mouthpiece of the Austrian employers' association, Die Arbeit, led a systematic campaign for a strengthening of state repression in view of the "legal uncertainty" that led "in almost every strike to unprecedented strike violence" and forced employers to find remedy against "strike terrorism." 39 Individual employers also used this language. In a letter to the Interior Ministry, an employer in Traisen (Lower Austria) denounced "the alarming increase (Überhandnehmen) in social democratic terrorism" and called for more repressive measures against picketing. ${ }^{40}$ The notion of "terrorism" was found in both the German-speaking and the Czech-speaking presses. A conservative Czech newspaper, for example, condemned the "terror in the name of freedom" against nonunionized workers in factories in Prague, who were subjected to verbal threats while the unions applied pressure to have them dismissed." ${ }^{41}$ Complaints also made their way into Parliament, where calls for better protection of willing workers were supported by German nationalists. An interpellation in the Reichsrat against the "brutal violence" used by social democrats to force workers to join strikes criticized the state for tolerating "terrorist activities," which threatened the "safety and lives" of "willing workers," while the power of "terrorist organizations" rapidly increased. ${ }^{42}$ Remarkably, the attacks against the labor movement also echoed in rural circles, for example, during a demonstration by agrarians against strikes in Vienna, which denounced strike terrorism. ${ }^{43}$

In 1906, the Austrian Union of Employers sent a memorandum to the Interior Ministry calling for reform to the law on coalition freedom and the banning of picket lines. Many employers sent separate correspondences to the ministry in support of legislative change. ${ }^{44}$ In 1909, a petition organized by the employers' associations and promoted by the Christian Social Party calling for reform of the right to strike and the protection of willing workers was submitted to Parliament. It bore the signatures of almost two hundred thousand Austrian employers. ${ }^{45}$ In 1910, German industrialists started a similar campaign for better protection of strikebreakers, the intervention of the army, and the demonstrative use of

\footnotetext{
${ }^{37}$ See Der Bund, December 19, 1909, 1.

${ }^{38}$ Bund österreichischer Industrieller: Mittelungen 9, no. 15 (October 1, 1907): 4-5.

${ }^{39}$ Die Arbeit, August 6, 1911, 3. For complaints about insufficient protection and the "coercion of workwilling workers," see Die Arbeit, May 31, 1908, 10.

${ }^{40}$ Letter from an employer in Traisen to the Interior Ministry, ÖStA, AVA, MdI, Präs, sig. 20/9, K1990, no. 3699/06, April 25, 1906.

${ }^{41}$ Národní politika, October 17, 1906, 6.

${ }^{42}$ ÖStA, AVA, MdI, Präs, sig. 20/9, K1990, no. 1768/06, "Interpellation des Abgeordneten Herzog und Genossen," February 19, 1906.

${ }^{43}$ Teplitz-Schönauer Anzeiger, November 16, 1910, 2.

${ }^{44}$ Many examples of letters sent to the Interior Ministry can be found at ÖStA, AVA, MdI, Präs, sig. 20/9, K1991, no. 4166/06.

${ }^{45}$ Neue Schlesische Zeitung, May 13, 1909, 2.
} 
machine guns against striking mineworkers in the Ruhr areas. ${ }^{46}$ That same year, the most influential German conservative newspaper, the Kreuzzeitung, published a long article on the responsibility of the state to protect willing workers. Wilhelm II enthusiastically read the article and tried again to pressurize the Prussian government into approving more restrictive legislation. ${ }^{47}$

Although neither German nor Austrian conservatives were successful in implementing a bill to formally penalize picketing, the existing legislation and decisions of the courts were already quite repressive. ${ }^{48}$ In Habsburg Austria, local measures of repression were sometimes harsher than the formal regulations. In Asch/Aš (Bohemia), for example, the local prefect published a proclamation completely forbidding picketing during a textile workers' strike. ${ }^{49}$ In Germany, shortly before the repressive law against picketing was definitively abandoned in 1900, the highly popular satirical magazine, Simplicissimus, featured a caricature of two gendarmes exclaiming "violence is still possible even without the new repressive laws." 50 Prussian courts gave out heavy sentences not only for verbal threats and low-level violence against strikebreakers, but also for insults and defamation (Ehrverletzung). ${ }^{51}$ Using the term strikebreaker to insult someone often resulted in a prison sentence. Legal disputes over honor formed part of everyday life in the German Kaiserreich, and lawsuits for insults meted out during strikes shaped labor relations. ${ }^{52}$ Severe punishments for defamation were also common in Austria, where Ehrenbeleidigung lawsuits were brought over use of the term strikebreaker. The Union of Industrialists applauded a decision by the Supreme Court of Justice in 1907 to consider accusations of strikebreaking as defamation. ${ }^{53}$ A gilder, for example, attacked the newspaper Arbeiterwille for having called him a "strikebreaker," and book printers whose names had been included in a list of strikebreakers in the Salzburger Wacht also objected to this particular term. In both cases, the editors were fined. ${ }^{54}$ Any attempt at moral punishment or social shaming of strikebreakers could be construed as an attack against their honor. ${ }^{55}$

Pressure to change legislation was only one of the means available to employers to counter strikes. Around the turn of the century, employers mounted a coordinated counterattack. They created associations at country level, which became progressively more centralized. ${ }^{56}$

\footnotetext{
${ }^{46}$ See Klaus Saul, "Repression or Integration? The State, Trade Unions and Industrial Disputes in Imperial Germany," in The Development of Trade Unionism in Great Britain and Germany, 1880-1914, ed. Wolfgang J. Mommsen and Hans-Gerhard Husung (London: Routledge, 1985), 338-56.

${ }^{47}$ Reinhold Zilch, ed., Die Protokolle des Preußischen Staatsministeriums 1817-1934/38, vol. 10, 14. Juli 1909 bis 11. November 1918 (Hildesheim: Olms-Weidmann, 1999), 63.

${ }^{48}$ See Anja Johansen, Soldiers as Police: The French and Prussian Armies and the Policing of Popular Protest, 1889-1914 (Aldershot: Ashgate, 2005), 118-19.

${ }^{49}$ Interpellation Rieger, ÖStA, AVA, MdI, Präs, K1991, sig. 20/9, no. 3493/06, February 21, 1905.

${ }^{50}$ Simplicissimus, September 16, 1899, 193.

${ }^{51}$ Ulrich Lappenküper, Otto von Bismarck und das "lange 19. Jahrhundert": Lebendige Vergangenheit im Spiegel der "Friedrichsruher Beiträge" 1996-2016 (Paderborn: Ferdinand Schöningh, 2017), 346.

${ }^{52}$ See Ann Goldberg, Honor, Politics, and the Law in Imperial Germany, 1871-1914 (Cambridge: Cambridge University Press, 2010), 60.

${ }^{53}$ Bund österreichischer Industrieller: Mitteilungen 11, no. 13 (September 15, 1909): 5.

${ }^{54}$ Arbeiterwille, March 9, 1910, 5; Salzburger Wacht, February 24, 1914, 5.

${ }^{55} \mathrm{On}$ the rituals of shaming against noncooperative workers in England, see Thomas Linehan, Scabs and Traitors: Taboo, Violence and Punishment in Labour Disputes in Britain, 1760-1871 (London: Routledge, 2018).

${ }^{56}$ The Bund der Industriellen in Germany (1895), the Verein deutscher Arbeitsgeberverbände (1904), the Centralverband der Industriellen Österreichs (1892), and the Bund der österreichischen Industriellen (1897). See
} 
These associations promoted effective measures against strikes, from lockouts to blacklisting or subscriptions to strike insurance. ${ }^{57}$ They also quickly created and maintained strong personal and institutional links with similar organizations abroad, such as those between Germany and Switzerland. ${ }^{58}$ As workers began to organize international networks, so did employers seeking solutions to the threat of strikes. ${ }^{59}$ In 1910, for example, the building contractors' associations of Germany, Austria, and Switzerland signed an agreement not to hire striking or locked-out workers. ${ }^{60}$

Employers and politicians keenly followed the developments in strike management in neighboring countries. Reports in the Austrian press, for example, often commented on the situation in Germany. ${ }^{61}$ The canton of Zurich, where picket lines had been temporarily banned in 1906, was seen as a model. ${ }^{62}$ During a Reichstag debate in 1907, the conservative Willibald von Dirksen enthusiastically reported that Italian Prime Minister Giolitti and French Premier Clemenceau had defended state intervention in protecting willing workers and described the use of soldiers as strikebreakers in place of railway workers. ${ }^{63}$ Furthermore, and more importantly, the Swedish general strike of 1909, one of the longest and most extensive social conflicts of the period, was studied by both German and Austrian employers as an example of a total defeat of the unions to be emulated. Pamphlets on the strike were published in Germany, Switzerland, and Austria. ${ }^{64}$ The director of the Swedish Employers' Association even came to Vienna in February 1910 to give a speech on the lessons to be drawn from this experience; he drew particular attention to the Swedish employers' organizational strength, their mutual strike insurance schemes, their use of civic militias, and state support, and concluded that as long as there was solidarity among employers and state support, "we and bourgeois society have nothing to fear from a general strike." 65

Employers and conservative politicians also stressed the urgent need to support the new associations of "patriotic," "loyal," or "yellow" workers that had rapidly spread on a transnational scale in the decade up to 1914. Inspired by the French right-wing "yellow" associations (originally created in Montceau-les-Mines in 1899), the well-organized German

Hans-Peter Ullmann, Der Bund der Industriellen. Organisation, Einfluß und Politik klein- und mittelbetrieblicher Industrieller im Deutschen Kaiserreich 1895-1914 (Göttingen: Vandenhoeck \& Ruprecht, 1976).

${ }^{57}$ Hans-Peter Ullmann, "Unternehmerschaft, Arbeitgeberverbände und Streikbewegung 1890-1914," in Streik. Zur Geschichte des Arbeitskampfes in Deutschland während der Industrialisierung, ed. Klaus Tenfelde and Heinrich Volkmann (Munich: C. H. Beck, 1981), 194-208; on blacklisting in Austria, see Bund österreichischer Industrieller: Mitteilungen, IX, 13-14, August 12, 1907, 6-7.

${ }^{58}$ See Pierre Eichenberger, Mainmise sur l'Etat social: Mobilisation patronale et caisses de compensation en Suisse (1908-1960) (Neuchâtel: Editions Alphil, 2016), 86-96, esp. 95.

${ }^{59}$ See Delalande, La Lutte et l'entraide, 236-37.

${ }^{60}$ Koller, "Local Strikes as Transnational Events," 313.

${ }^{61}$ See Die Arbeit, August 18, 1912, 1.

${ }^{62}$ See Christian Koller, Streikkultur. Performanzen und Diskurse des Arbeitskampfes im schweizerischösterreichischen Vergleich (1860-1950) (Vienna: Lit Verlag, 2009), 134; reports on strong measures in the Zurich canton against strikers in Grazer Tagblatt, June 10, 1913, 13.

${ }^{63}$ Reichstagprotokolle, vol. 9.1, April 15, 1907, 770.

${ }^{64}$ Fritz Tänzler, Der Generalstreik in Schweden 1909 (Berlin: Zillessen, 1909); Aloys von Liechtenstein, Der schwedische Generalstreik (Vienna: Dworak, 1910); Otto Steinmann, Betrachtungen über den schwedischen Generalstreik des Jahres 1909 (Zurich: Zentralverband Schweiz. Arbeitgeber-Organisationen, 1910).

${ }^{65}$ Bund österreichischer Industrieller: Mitteilungen 12, no. 3 (March 12, 1910): 4; see also Die Arbeit, February 13, 1910, 2-3; Die Arbeit, May 15, 1910, 2. 
counterstrike front created unions that were favorable to employers and committed to opposing strikes. ${ }^{66}$ Employers and right-wing pressure groups often financed them directly or indirectly, and accorded minor benefits to the members of these unions in exchange for loyalty and non-engagement in strike action, the idea being to create a counter-workers' movement as a tool against social democracy. The yellow movement developed in Austria over the following years, and the employers who promoted it made explicit reference to its being based on the German model. ${ }^{67}$ As a Czech union newspaper remarked, although the yellow movement was presented as a national movement in Germany and in Austria, it was an international phenomenon: "The yellow movement in France influenced the yellow unions' movement in Germany, which was in turn transferred from there to Austria." 68

The fact that yellow unions were mostly described as "patriotic" or "loyal to the empire," at least in the German case, was not a coincidence. The counter-mobilization against strike terrorism had a major impact on political polarization as it created links between internal and external enemies, antisocialism and nationalism. In June 1897, Wilhelm II delivered a speech in Bielefeld critical of "revolutionary subversion" during labor disputes. The kaiser's speech was similar in tone to his notorious Hun speech against the Boxer Rebellion, although in Bielefeld he threatened internal enemies with "ruthless repression." 69 Historians have considered the ruthless representation of political enemies as criminals and "beasts in human form" as a key precondition for the escalation of violence in the early Weimar years. ${ }^{70}$ However, this violent discourse was already widespread in Wilhelmine Germany. Kuno von Westarp, a key figure in the German right in the early Weimar years, delivered many speeches in the Reichstag around 1910 in which he created a polar opposition between "patriotic workers" and "strike terrorism," labeling the latter social democratic before 1914, and Bolshevik after the November Revolution. ${ }^{71}$ Conversely, central European social democratic newspapers and the trade union press referred to strikebreakers in rather brutal, intimidatory tones. The Swiss newspaper Grütlianer, for example, insulted the strikebreakers, calling them Judas souls, or suggesting they were doing the disgusting work of an executioner's servant (abscheuliche Henkersknechtdienst), and published their home addresses, inciting readers to attack them. ${ }^{72}$ Strikebreakers in Prague were branded as traitors with threats posted on their house doors. ${ }^{73}$ This raises fresh questions about the roots of the

\footnotetext{
${ }^{66}$ Edward J. Arnold, "Counter-Revolutionary Themes and the Working Class in France of the Belle Époque: The Case of the Syndicats Jaunes, 1899-1912,” French History 13, no. 2 (1999): 99-133.

${ }^{67}$ Die Gelbe Bewegung (Vienna: Hauptstelle industrieller Arbeitgeber-Organisationen, 1909), 13.

${ }^{68}$ Solidarita, October 22, 1908, 1.

${ }^{69}$ Edgar Feuchtwanger, Imperial Germany 1850-1918 (London and New York: Routledge, 2001), 129.

${ }^{70}$ Mark Jones, Founding Weimar: Violence and the German Revolution of 1918-1919 (Cambridge: Cambridge University Press, 2016).

${ }^{71}$ See, for example, Reichstagprotokolle, vol. 14.1, February 15, 1912, 45; Reichstagprotokolle, vol. 14.4, January 14, 1913, 2940. See also Daniela Gasteiger, Kuno von Westarp (1864-1945). Parlamentarismus, Monarchismus und Herrschaftsutopien im deutschen Konservatismus (Berlin: De Gruyter, 2018), 192. Antisocialism in Wilhelmine Germany as well as the anti-Bolshevism in the early Weimar years were ideologically and semantically interwoven not only with nationalism, but also with colonial racism, especially after the genocide of the Herero and Nama people in southwest Africa and the "Hottentot election" of 1907. See Frank Oliver Sobich, "Schwarze Bestien, rote Gefahr." Rassismus und Antisozialismus im deutschen Kaiserreich (Frankfurt: Campus, 2006).

${ }^{72}$ Grütlianer, May 31, 1906, 1. See also Grütlianer, June 26, 1906, 4, and June 27, 1907, 6.

${ }^{73}$ See daily report from Prague Police Headquarters, ÖStA, AVA, MdI, Präs, K1990, no. 782/06, January $21,1906$.
} 
political violence that escalated at an unprecedented rate after the Great War in the former Hohenzollern and Habsburg empires. In the prewar period, there is undoubtedly a certain gap between the negative discursive construction of strike terrorism and the social reality of largely peaceful strikes and political demonstrations. After 1918, this gap disappeared, and the experienced brutality of the political conflicts sometimes even transcended the discursive violence in media representations.

The gap between discourses and social reality does not mean that episodes of violence and radicalization were a marginal concern in prewar societies. The narrative of strike terrorism was not completely disconnected from reality, and violence was embedded in the context of labor migration and strikebreaking. The hiring of foreign workers was not a new practice at the turn of the century, but it grew in importance in the context of an increasingly mobile workforce and employers even more determined to forcefully counter strike actions. The professionalization of strikebreakers was linked to the increased mobility of labor within central Europe at the turn of the century, which created an integrated European labor migration space dominated by private agents who used questionable practices to exploit migrant workers. In the next section, we will focus on these aspects in order to shed light on the context in which the narrative of strike terrorism found fertile soil and generated social tensions, fears, and low-level violence before 1914.

\section{Labor Migration and Strikebreaking Agents}

Over the two decades before the outbreak of the First World War, Germany had become the second destination country for immigration in the world: between 1871 and 1910, the number of foreigners rose from 260,000 to 1.2 million. ${ }^{74}$ Throughout this period AustriaHungary was the foremost country of origin of foreign workers in Germany: in 1907, 40 percent of foreigners employed in Germany came from Austria-Hungary, 24 percent from Russia, and 14 percent from Italy (mostly the northern regions). ${ }^{75}$ Germany, northern Italy, Switzerland, Austria-Hungary, and Russian Poland constituted a closely interdependent labor market, with emigration preponderant in some regions and immigration in others. Emigration from the Austrian half of the empire grew in importance around the turn of the century, equivalent to 5 percent of the population in $1900 .^{76}$ The majority of the cross-border migrants went to Germany (more than went overseas). More than half the Austrian workers in Germany worked in mining, industry, and the building trade. ${ }^{77}$ Seasonal agricultural workers, many from Galicia, formed another significant proportion of emigrants, although their numbers are difficult to estimate (approximately two hundred

\footnotetext{
${ }^{74}$ Jochen Oltmer, Migration im 19. und 20. Jahrhundert (Munich: R. Oldenbourg, 2010), 32; Ulrich Herbert, Geschichte der Ausländerbeschäftigung: Saisonarbeiter, Zwangsarbeiter, Gastarbeiter, Flüchtlinge (Munich: C. H. Beck, 2001), 24.

${ }^{75}$ Klaus J. Bade, "Land oder Arbeit? Transnationale und interne Migration im deutschen Nordosten vor dem Ersten Weltkrieg” (Habilitationsschrift, University of Erlangen-Nürnberg, 1979), 499. See also Herbert, Geschichte der Ausländerbeschäftigung, 55.

${ }^{76}$ Andrea Komlosy, "State, Regions, and Borders: Single Market Formation and Labor Migration in the Habsburg Monarchy, 1750-1918," Review (Fernand Braudel Center) 27, no. 2 (2004): 135-77, esp. 154.

${ }^{77}$ Annemarie Steidl, "Migration Patterns in the Late Habsburg Empire," in Migration in Austria, ed. Günter Bischof and Dirk Rupnow (New Orleans: University of New Orleans Press, 2017), 76-77.
} 
thousand in 1912). ${ }^{78}$ While internal migration to the industrial centers of the Habsburg empire mostly originated from the core regions of the empire (present-day Austria and the Bohemian lands), Galician workers tended to move abroad, especially to Germany.

Moving from one country to another for work heavily relied on the business of private agents, who provided a link between employer and manpower, and emerged as key players in central European labor migration. Agents in Habsburg Austria recruited candidates for immigration for the benefit of German industry and landowners, as well as for German shipping companies, and earned a commission for each new recruit. As shown in the case of overseas migration, agents were indispensable in navigating the difficulties of the journey and government restrictions. ${ }^{79}$ The extent to which they actually stimulated emigration instead of simply facilitating it is debatable, but their presence on the Austrian territory is not. ${ }^{80}$ Galicia, especially, was described as an "agents' paradise," with agents competing to attract migrants to German ships, German mines, or German fields. ${ }^{81}$ Border towns, such as Óswiecim (Auschwitz), were crawling with agents and their subagents recruiting newcomers in search of work and travel in nearby Germany. ${ }^{82}$ In the mining border region of Austrian Silesia, the number of agents targeting miners significantly grew in the last years before the war. ${ }^{83}$ Miners also crossed the border illegally to benefit from higher Prussian wages. ${ }^{84}$ The phenomenon of German agents, however, was not confined to the Silesian-Galician border but also affected other regions of the monarchy. Areas of Carniola (present-day Slovenia), for example, were reportedly deserted with entire factories deprived of their workers due to the efficiency of agents working for German industry. ${ }^{85}$ The action of private agents in the recruitment and transportation of replacement workers during strikes was particularly controversial. In 1908, a social democratic newspaper conceded that "it cannot unfortunately be denied that German strikebreaking agents have repeatedly successfully found willing workers in Austria." 86

Contemporary accounts highlight the potential for abuse of power at the core of the agents' system in both the agricultural and industrial sectors. Agents with doubtful practices were accused of taking a very large cut of the field laborers' wages, and of exploiting their

\footnotetext{
${ }^{78}$ Annemarie Steidl, Engelbert Stockhammer, and Hermann Zeitlhofer, "Relations among Internal, Continental, and Transatlantic Migration in Late Imperial Austria," Social Science History 31, no. 1 (2007): 61-92, esp. 75 .

${ }^{79}$ Tara Zahra, "Travel Agents on Trial: Policing Mobility in East Central Europe, 1889-1989," Past E Present, no. 223 (2014): 161-93.

${ }^{80}$ James David Boyd, "Initiating Mass Movement: Questions of Commercial Information in Atlantic Migration from Central Europe, 1870-1900," Journal of Austrian-American History 2, no. 1 (2018): 31-50.

${ }^{81}$ Bade, "Land oder Arbeit?," 528.

${ }^{82}$ See Zahra, "Travel Agents on Trial," and also the description in Martin Pollack, Kaiser von Amerika. Die grosse Flucht aus Galizien (Vienna: Zsolnay, 2010); at the turn of the century, German shipping companies needed to expand their customer base as emigration from Germany diminished and thus successfully sent agents to eastern Europe, which became a prime market for them.

${ }^{83}$ See a report of activity from Mährisch Ostrau/Moravská Ostrava police for 1913, Zemský archiv v Opavě, Policejní ředitelství v Moravské Ostravě, ka 156, sig. 574, from the Silesian regional offices, July 28, 1914.

${ }^{84}$ Police report in Mährisch Ostrau/Moravská Ostrava police for 1913, Zemský archiv v Opavě, Policejní ředitelství v Moravské Ostravě, sig. 555, no. 209/1, March 20, 1914.

${ }^{85} \mathrm{This}$ problem is raised by one of the delegates at the conference about the central European labor market organized by central European economic associations with delegates from Germany, Austria, and Hungary: Verhandlungen der Budapester Konferenz betreffs Organisation des Arbeitsmarktes (Leipzig: Deichert, 1911), 103.

${ }^{86}$ Salzburger Wacht, March 2, 1908, 3.
} 


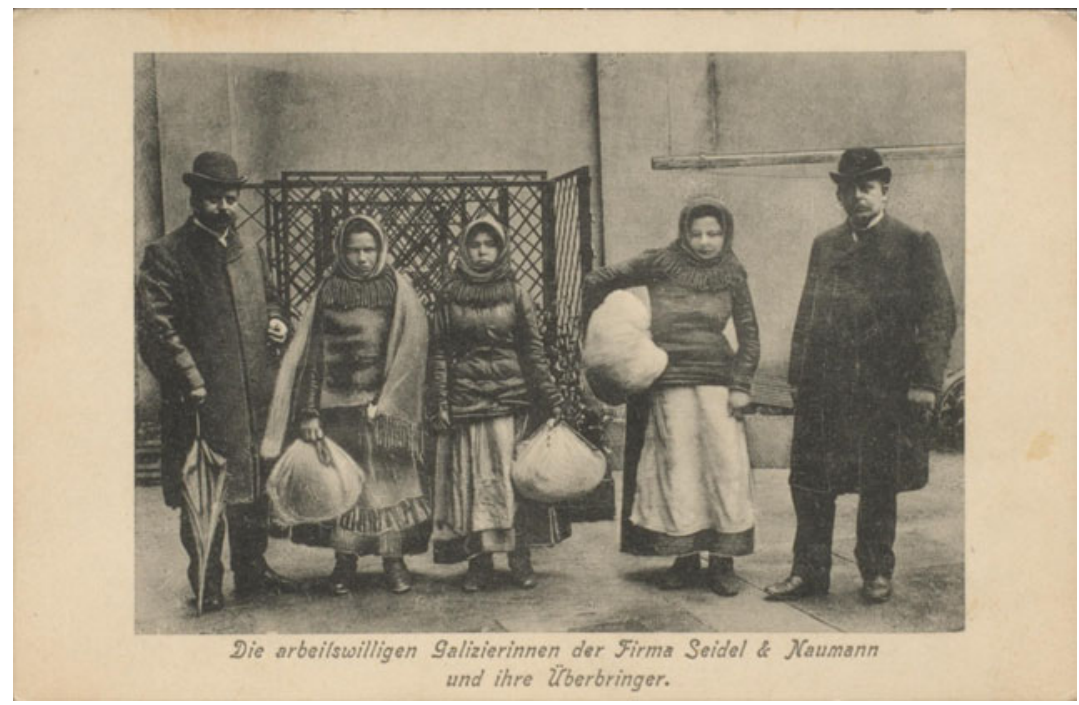

Fig. 1. Women from Galicia described as "willing workers" and the two strikebreaking agents who had recruited them and brought them to Germany. Source: Postcard, ca. 1910, FDGP Bezirkvorstand Dresden 12465, no. 2367, Hauptstaatsarchiv, Dresden, Germany.

ignorance of the German language to deceive them with regard to working conditions and pay. ${ }^{87}$ An official report by the Austrian Vice Consul in Germany in 1912 was very critical of the foremen who provided fieldworkers to estate owners in Germany. They were reported to have complete control over the agricultural workers, charging them for transport and meals, and in some cases also physically and sexually abusing them. The consul recommended restricting the trade of these private agents as they exerted too much power over the workers, distributing the work as they wanted, and having all the wages paid directly to themselves. $^{88}$

Agents were often compared to slave traders, and complaints about their unscrupulousness were frequent. In a discussion on the central European labor market, Polish lawyer Leopold Caro denounced the whole system of migration agents in Austria, quoting the words of the head of the German shipping company Norddeutsche Lloyd: "In Galicia we work with the scum of humanity." 89 In Germany, a large number of the private labor agents had previous criminal convictions. A Prussian survey from 1895 found that 11.3 percent of them had prior convictions, while 43.2 percent of agents in Bavaria had prior convictions in 1909, and 47.3 percent in 1914 (half of them for business crimes). ${ }^{90}$ The flourishing trade in human labor led to fierce competition among the seven thousand active

\footnotetext{
${ }^{87}$ Leopold Caro, Auswanderung und Auswanderungspolitik in Österreich (Leipzig: Duncker und Humblot, 1909), 146-54.

${ }^{88}$ Report from the Vice Consul in Germany, ÖStA, AVA, Ministerium für öffentliche Arbeiten (hereafter MföA), Allgemein, Fz 715, no. 11392 XV b 1913, December 20, 1912.

${ }^{89}$ Verhandlungen der Budapester Konferenz betreffs Organisation, 89.

${ }^{90}$ Marianne Daniels, "Die Entwicklung der Arbeitsnachweis-Organisationen in Deutschland von der Jahrhundertwende bis zum Gesetz über Arbeitsvermittlung und Arbeitslosenversicherung von 1927" (PhD diss., University of Munich, 1929), 28.
} 
agents (Menschenhändler), who were paid by both the employer and the worker ( 5 crowns each). ${ }^{91}$ Well-known German strikebreaking agents, such as Friedrich Hintze and Karl Katzmarek, also had criminal backgrounds; they were paid 10 marks for each strikebreaker they delivered, but passed on only a small percentage of this to the willing workers. ${ }^{92}$

Relying on agents also had drawbacks for employers. They sometimes encouraged workers to break their contracts or hired unfit workers simply to get the fee. As a result, Prussian landowners asked the state to intervene to regulate the business and get involved in labor mediation. Complaints led to the creation of the Deutsche Feldarbeiterzentralstelle in 1905. This organization (which in 1911 became the Deutsche Arbeiterzentrale) was a private agency under the control of the Prussian Agriculture Ministry, which had the task of finding and hiring foreign workers. After 1908, it also delivered official working permits for a fee, which revealed a combination of public and private in the regulation of Germany's eastern borders. ${ }^{93}$ The Prussian government wanted to provide cheap manpower for its large landowners while limiting the number of Poles settling in the region. It also struck a deal with the Ruthenian National Committee, which hoped that the emigration of seasonal workers to Prussia would be of benefit to their agricultural strike action at home. ${ }^{94}$ The Zentrale, however, continued to recruit mostly agricultural workers, and only very marginally industrial workers, which meant that industrialists from all over Germany continued to rely on private agents for their needs. ${ }^{95}$ In Austria, as well, there were attempts to regulate the agents' dealings. A regional 1909 decree in Galicia introduced rules for the business of recruiting workers, while in 1904 the empire-wide creation of public labor placement agencies intended to provide an alternative offer. ${ }^{96}$ In practice, these regulations did not put an end to the flourishing business of private agents, who often made additional money by providing accommodation and food to displaced migrants at extortionate rates. ${ }^{97}$

The emigration of Austrian industrial workers to Germany (195,664 in 1907, mostly employed in the mining, construction, metal, and textile industries) had gradually evolved from its initial phase, which saw men crossing the Bohemian and Silesian borders looking for better wages. A report from the Austrian consul in 1913 indicated that the German and Austrian agents' promotional efforts had extended recruitment to the whole empire. Complaints about the agents operating in Austrian mining areas were very similar to those

\footnotetext{
${ }^{91}$ Sebastian Conrad, Globalisierung und Nation im Deutschen Kaiserreich (Munich: C. H. Beck, 2006), 129. The figure of five crowns comes from Anton Knoke, Ausländische Wanderarbeiter in Deutschland (Leipzig: Deichert, 1911), 38; for more descriptions of agents' malpractices, see Johannes Nichtweiss, Die ausländischen Saisonarbeiter in der Landwirtschaft der östlichen und mittleren Gebiete des Deutschen Reiches, 1890-1914 (Berlin: Rütten \& Loening, 1959), 77-79.

${ }^{92}$ See Berliner Morgenpost, October 4, 1910, 1; Arbeiter-Zeitung, June 9, 1914, 10.

${ }^{93} \mathrm{On}$ the increased control of work migrants by the Prussian state, see Christiane Reinecke, Grenzen der Freizügigkeit. Migrationskontrolle in Großbritannien und Deutschland, 1880-1930 (Munich: Oldenbourg, 2010), 77-95. The combination of public and private is similar to the role of the shipping companies; see Tobias Brinkmann, "Why Paul Nathan Attacked Albert Ballin: The Transatlantic Mass Migration and the Privatization of Prussia's Eastern Border Inspection, 1886-1914," Central European History 43, no. 1 (2010), 47-83.

${ }^{94}$ Report from the Galician governor to the Interior Minister ÖStA, AVA, MdI, Präs, sig. 20/9, K1990, no. 3587, April 19, 1906.

${ }^{95}$ Knoke, Ausländische Wanderarbeiter in Deutschland, 43-44.

${ }^{96}$ Landesgesetzblatt Galizien, XX, no. 152 (1909): 257.

${ }^{97}$ Knoke, Ausländische Wanderarbeiter in Deutschland, 37-38.
} 
concerning the agricultural sector (unfulfilled promises, hiring of unfit workers). ${ }^{98}$ The aim of the emigration law discussed in 1912-1914 was to address these concerns and provide regulation: a 1913 draft required special authorization to practice the profession of agent and limited it to Austrian residents. ${ }^{99}$ One of the Habsburg officials' goals was to keep qualified employees for their home-grown industry. Austrian industry was suffering from a general manpower shortage, which, at least in Salzburg, Upper Austria, Carinthia, and Carniola, was partially due to emigration to Germany. ${ }^{100}$ The Austrian authorities therefore adopted a defensive attitude toward the agents' recruitment efforts. When the managers of mines in Prussian Upper Silesia (Kattowitz) asked the Galician governor for permission to send three agents to Galicia to recruit workers in 1913, they were turned down because of a labor shortage in mines in Austria. ${ }^{101}$ The Interior Ministry drafted an announcement to be published in newspapers and distributed in Austrian coal mines alerting workers to agents recruiting for work in Germany. "In most cases," warned the announcement, recruits either did not get work or had to work for lower pay, and then turned to consular authorities for help. ${ }^{102}$ The Austrian consul in Hamburg had dealt with such a case a few years earlier when 135 workers were recruited under false pretenses by private agents for a cement factory in Hannover. He had recommended sending warnings not only to Bohemia, where the workers had come from, but also to Styria, Lower and Upper Austria, and Galicia, places where the agents might try to recruit. ${ }^{103}$ During a masons' strike in Berlin in 1907, several agents (five, reportedly) traveled to Moravia to recruit workers promising greater pay and to cover travel costs. Local authorities monitored their activities because the workers ran the risks of being threatened by the Berlin strikers once they arrived and being sent back as penniless foreigners at the expense of their hometowns. ${ }^{104}$

Warnings came not only from government officials concerned about losing their local workforce, but also from social democrats who saw cross-border recruitment as a means of weakening strikes in neighboring countries. Attempts to inform workers in the countries of origin were part of a broader strategy of solidarity to help ensure the success of strikes abroad. The importation of foreign labor became a major concern for international trade unions and was officially condemned at their international congresses in 1907 and 1909. ${ }^{105}$ Austrian social democrats saw the role of their country in this dynamic as a labor reservoir, and therefore issued warnings against German agents. On a construction workers' lockout in Germany in 1910, the Arbeiter-Zeitung wrote: "We must arm ourselves

\footnotetext{
${ }^{98}$ Report from the Vice Consul in Germany, ÖStA, AVA, MföA, Allgemein, Fz 715, no. 12293 XV b 204, January 15, 1913.

${ }^{99}$ The law never came into effect. On the project, see Zahra, "Travel Agents on Trial," 171. For the text of the draft submitted by the Minister of Industry, see ÖStA, AVA, MföA, Allgemein, Fz 715, no. 6977 XV b, February 4, 1913.

${ }^{100}$ See the reports from local branches of the Union of Industrialists, Bund österreichischer Industrieller. Mitteilungen 9, no. 17-18 (November 14, 1907): 3.

${ }^{101}$ ÖStA, AVA, MföA, Allgemein, Fz 715, no. 55345 XV b, October 11, 1913.

${ }^{102}$ ÖStA, AVA, MföA, Allgemein, Fz 715, 6243, July 31, 1913.

${ }^{103}$ ÖStA, AVA, Handelsministerium, Fz 492, no. 12810/07, April 19, 1907.

${ }^{104}$ See the report from the police headquarters in Brünn/Brno, Moravský zemský archiv (Moravian Regional Archives, Brno, MZA), Moravské místodrzitelství-presidium (Presidium of the Governor's Office, B13), ka 377, sig. 1, no. 6806, July 6, 1907; see also, report from the district in Wischau/Vyškov July 27, 1907, and other towns in Moravia in the same folder.

${ }^{105}$ Delalande, La Lutte et l'entraide, 240.
} 
with caution, and all workers must observe every labor agent with complete mistrust. Strikebreaking agents, which have appeared in Leoben, will try in every place and with every conceivable lie to recruit Austrian workers to serve as the auxiliary troops of employers in Germany...."106 In 1910, an editor of the same newspaper traveled to Croatia, Dalmatia, and Carniola to prevent workers being recruited by Swiss agents who were hiring throughout the Habsburg monarchy for the Winterthur building contractors. ${ }^{107}$ Warnings to prevent the influx of manpower that included descriptions of the true working conditions regularly featured in the German-speaking and Czech-speaking press in Austria. ${ }^{108}$ Social democrats also led direct actions to prevent workers from going abroad: at the train station in Brünn/Brno, as thirty masons boarded a train to reach Braunschweig where they had been recruited by a local foreman, twenty-five unionized workers came to the train platform to dissuade them from traveling and inform them of the strike. The police quickly dispersed them, and the workers left for Germany. ${ }^{109}$ This propaganda also aimed to counter the negative representations of foreign workers held by German workers, which became more widespread after the turn of the century. Even in a place of long-standing intense exchanges and migrations such as the southern border of Saxony, Bohemians (and especially Czech speakers) were stereotyped as strikebreakers. ${ }^{110}$ Italian workers also suffered from a negative image as strikebreakers, which worried even the Italian foreign minister, Antonino di San Giuliano. In a speech to parliament, he argued that the negative international image of Italian workers was having repercussions on Italy's international prestige. ${ }^{111}$

The example of Italy shows the active efforts of social democrats, and, in part, also of state authorities to counter strikebreaking abroad through information. The aforementioned strike among German construction workers in 1910 led the Italian government to send a communication to all the prefects to inform workers intending to travel to Germany of the unfavorable situation and to warn them of the risks involved in acting as strikebreakers. ${ }^{112}$ The Italian delegation at the International Socialist Workers' Congress of 1893 conceded that work migrants had a "detrimental influence" because they "depress wages, prevent strikes and give rise to sometimes fierce conflict," 113 and proposed putting out targeted propaganda as a countermeasure. The Italian-language newspaper L'operaio italiano (The Italian Worker), promoted by the German Free Unions and published in Berlin from 1898 to 1914,

\footnotetext{
${ }^{106}$ Arbeiter-Zeitung, April 14, 1910, 8.

${ }^{107}$ Christian Koller, "Local Strikes as Transnational Events," 310. An announcement in a Bohemian newspaper read: "In the next days there will again appear in all parts of Austria agents who look for workers for construction work in Winterthur (Switzerland).... As sleeping places, the masters give regular barns where the wind whistles. The promised salary is not paid ... The masters from Winterthur are chauvinists who see all non-Swiss as lower-value men ... Workers don't go to Winterthur!" Böhmerwald Volksbote, February 11, 1910, 7.

${ }^{108}$ Examples: Swiss agents operating in Tyrol and Carinthia, Arbeiterwille, August 14, 1910, 11; warning against agents in Linz, Vienna, and Passau for a dockers' strike in Passau, Arbeiter-Zeitung, October 17, 1906, 11; spinners in Bohemia, as well as Upper and Lower Austria warned against agents from a firm in Bavaria, Böhmerwald Volksbote, June 14, 1913, 7; warning in the Czech press after an advertisement by German metal factories in the journal of Austrian industrialists, Nová doba, August 28, 1911, 2.

${ }^{109}$ Daily police report Brünn/Brno, 16 August 1906, MZA, B13, ka 374, sig. 1, no. 6665/06.

${ }^{110}$ Murdock, Changing Places, 42-44.

${ }^{111}$ Atti parlamentari (Rome, 1910), vol. 7, 8691. The Austrian Salzburger Wacht positively commented on San Giuliano's critique against "Streikbrechertum," Salzburger Wacht, August 29, 1910, 2.

${ }^{112}$ Atti parlamentari (Rome, 1910), vol. 6, 7353-55.

${ }^{113}$ Protokoll des Internationalen Sozialistischen Arbeiterkongresses (Zurich, 1894), 50.
} 
offered a means to inform Italian migrants and militated against strikebreaking. In a joint German, Swiss, and Austrian mission, social democrat agitators were sent to disseminate information in Italy in the winter when workers returned home, albeit without much success. ${ }^{114}$

Work migrants were indeed less likely to be unionized ${ }^{115}$ because the high level of mobility, with many return or seasonal movements, made joining a union less attractive. ${ }^{116}$ Lack of information also made recruitment easier, as a Catholic priest explained in his diary in 1905: "These people are fetched by unscrupulous agents who promise them high wages while concealing the strike or lockout." 117 The newspapers of the German unions had in 1902 already noticed the positive effect of propaganda efforts among Italian workers in reducing strikebreaking. However, this strategy was only efficient against "unwitting strikebreakers" but not against the professionals, "the worst elements on earth," who targeted factories on strike and ransomed the unions by threatening to take on work. ${ }^{118}$

Efforts to spread information translocally were a weak weapon against the growing professionalization of organized strikebreakers, who explicitly offered a full service, including transportation and protection, to employers all over Germany and across borders. An article from 1914 in the Czech glassmakers' journal entitled "Slave Traders" described the rise of this transnational business:

In Europe, it is especially in Germany that many of these questionable men have for some time been organized into a proper protection army against "upheaval and revolution." Now, however, seems to be a flourishing period for these gentlemen, who are in fact more concerned with their bag of money than with the factory of the employer affected by the strike. German employers spotted very quickly the type of "workforce" offered by these agencies... This is why they are now looking for new fertile fields, where they can still make considerable gains with their procurement of strikebreakers, and they have guessed that they would find them where fools do not die out, that is, in Austria. ${ }^{119}$

The article went on to quote an advertising letter from a German strikebreaking agent to a factory owner in Austria, offering to supply him with workers. The advertisement even proposed to provide favorable references. Another newspaper quoted a letter sent from August Müller's international labor recruitment agency in Hamburg to the association of metal workers in Reichenberg/Liberec (Bohemia) asking "if it would be possible to get from you people prepared to work during strikes." 120 This company, created in 1906, had established an international strikebreaking business and was also used by Swiss building firms during the Winterthur strike. ${ }^{121}$ As mentioned in the introduction, the social democratic

\footnotetext{
${ }^{114}$ See Luigi Rossi, L'operaio italiano: periodico in lingua italiana dei Liberi Sindacati Tedeschi (1898-1914) (Mantova: Associazione Mantovani nel Mondo, 2007). For an overview of the history of Italian labor migration in Wilhelmine Germany, see René Del Fabbro, "Wanderarbeiter oder Einwanderer?. Die italienischen Arbeitsmigranten in der Wilhelminischen Gesellschaft," Archiv für Sozialgeschichte 32 (1992): 207-29.

${ }^{115}$ Only 5 percent of Italians working in Germany were unionized in 1912. Herbert, Geschichte der Ausländerbeschäftigung, 70 .

${ }^{116}$ This was also true for other types of mobility, see Dieter Langewiesche, "Wanderungsbewegungen in der Hochindustrialisierungsperiode. Regionale, interstädtische und innerstädtische Mobilität in Deutschland 1880-1914," Vierteljahrschrift für Sozial- und Wirtschaftsgeschichte 64, no. 1 (1977): 1-40.

${ }^{117}$ Del Fabbro, "Wanderarbeiter oder Einwanderer?" 224.

${ }^{118}$ Correspondenzblatt der Generalkommission der Gewerkschaften Deutschlands 12, no. 31 (August 4, 1902): 539.

${ }^{119}$ Solidarita, January 8, 1914, 1.

${ }^{120}$ Deutsches Nordmährerblatt, August 28, 1910, 3.

${ }^{121}$ Koller, "Local Strikes as Transnational Events," 310.
} 
press equated this business with the white slave trade and reported that workers had been "sold as slaves" and "transported like cattle." 122 Comparisons with the slave trade reflect a wider panic over the enslavement of vulnerable populations and their treatment at the hands of agents, which was important in both the anti-emigration and anti-prostitution discourses in the late Habsburg empire. ${ }^{123}$ Indeed, both migration streams were intertwined: the figure of the migration agent and the sex trafficker were often fused and viewed as a danger for "gullible" eastern Europeans. ${ }^{124}$ The international mobilization against the trafficking of young girls, which culminated with the 1910 Paris Convention for the Suppression of the White Slave Traffic, was, however, more developed among bourgeois circles and conceived as a moral mission. ${ }^{125}$

The discourse and social reality of "slave handlers" on the one hand and "strike terrorism" on the other were embedded in the same context of heightened social conflicts, perceived threats, and the new challenges that state authorities, political parties, employers, and trade unions had to face in the prewar years. The next section will show how tensions related to labor migration and strikebreaking were manifested in critical episodes of brutal repression, and how German and Austrian authorities handled them. We will argue that these episodes highlight a new dimension of violence emerging before 1914.

\section{Violent Professionals and Lenient Authorities}

Strikebreaking agents were not only recruiting and bringing in workers, but were also engaging in violent confrontations with the strikers. In their advertisements to companies, they presented their activities as a regular profession. The professionalization of strikebreakers was even discussed in the German Reichstag, where in 1913 the SPD deputy Oskar Cohn noted that strikebreaking had become a profession in itself and the recruitment of strikebreakers a business. ${ }^{126}$ In the decade before the First World War, the groups led by Friedrich Hintze in Hamburg and Karl Katzmarek in Berlin emerged as the most powerful strikebreaking agencies in Imperial Germany. These bands of strikebreakers were highly professionalized and active in almost all of German-speaking central Europe. They were well known for their brutality and their use of weapons as a main part of their everyday business. Katzmarek's and Hintze's names became synonymous with professional strikebreaking using brutal methods, and the terms Hintzebrïder, Hintzegarde, or Katzmareks were used to insult nonstriking workers or to emphatically describe other armed groups of strikebreakers. ${ }^{127}$ An Austrian social democratic newspaper highlighted the international fame of German

\footnotetext{
${ }^{122}$ Salzburger Wacht, February 7, 1911, 4.

${ }^{123}$ For a critical discussion of these discourses, including their antisemitic dimensions: see on emigration, Zahra, "Travel Agents on Trial." On prostitution agents as modern-day slave traders, see Nancy Wingfield, The World of Prostitution in Late Imperial Austria (Oxford: Oxford University Press, 2017), chap. 6; on earlier representations of emigration agents as slave traders, see the work of William O'Reilly, "Migration, Recruitment and the Law: Europe Responds to the Atlantic World," in Atlantic History. History of the Atlantic System 1580-1830, ed. Horst Pietschmann (Göttingen: Vandenhoek \& Rupprecht Verlag, 2002), 119-37, esp. 126-27.

${ }^{124}$ Keely Haulster-Stated, The Devil's Chain: Prostitution and Social Control in Partitioned Poland (Cornell: Cornell University Press, 2015), 137-68.

${ }^{125}$ Wingfield, The World of Prostitution in Late Imperial Austria, 202.

${ }^{126}$ Reichstagsrede, February 8, 1913 ("Streikbrecher, Arbeitswilliger sein, ist heutzutage ein Beruf").

${ }^{127}$ For this reason, it is sometimes unclear whether Hintze and Katzmarek were directly involved, or if their names were used by social democratic newspapers to describe other armed groups of strikebreakers.
} 
gangs: "As capitalism pursues everything internationally, the recruitment of strikebreakers is also organized internationally. In Germany, a gang of publicly dangerous elements has formed, which has acquired under the name Hintzegarde, a European, though terrible, reputation. These fellows are professional strikebreakers in the true sense of the word.... They do not limit their actions to Germany but also go abroad. They were recently in Zurich and now a column has been recruited to Innsbruck to break the local carpenters' strike."128 When the director of a Bavarian sanatorium threatened with a revolver picketing men who prevented sixty workers recruited from Upper Austria getting off the train, the same newspaper remarked ironically that the doctor had "missed his calling" and should instead join the "Hintze men" as a strikebreaking agent. ${ }^{129}$

Friedrich Hintze even gave a long interview to the popular newspaper Berliner Morgenpost, in which he described his career as a professional strikebreaker and provided insights into how he organized his business. ${ }^{130}$ Hintze initially worked for the aforementioned August Müller recruitment agency in Hamburg, but shortly after Müller's death he formed his own organization. He claimed to have more than six thousand strikebreakers that he could mobilize in only eight days. Although this claim was obviously exaggerated, Hintze was able to organize quite large groups of armed strikebreakers with long-range mobility. In 1911, according to Vorwärts, hundreds of "Hintze's soldiers" traveled from Hamburg to the East Prussian city of Königsberg, a distance of nearly 900 kilometers. Berlin and Hamburg were the most important logistics centers from which strikebreakers could reach remote cities like Königsberg, although they more frequently operated in the regional areas of cities such as Bremen and Kassel, as well as many small towns in Brandenburg and Mecklenburg. The motivations of professional strikebreakers were primarily economical: they saw it as an opportunity for easy money, even though their activities were then exploited politically.

In his interview to the Morgenpost, Hintze pointed out that his services were not limited to labor replacement but also included supplies, logistics (he had three transport vehicles), and organizing the "self-defense" of strikebreakers against unionized workers. Hintze was aware that the interview with the Morgenpost was a great opportunity for free publicity. He mentioned that his strikebreakers did any job the company would pay for, but more importantly, they would intimidate unionized workers. Hintze proudly asserted: "With thirty men I can terrify five hundred strikers." 131 Other German strikebreaking agents with criminal backgrounds, such as Joseph Ruppert, who killed a striking worker near Magdeburg in 1912, openly admitted that violent intimidation was part of their job and that therefore "weapons are our working equipment."132

The professionalization and militarization of strikebreaking was a response to the employers' demand for security against strike terrorism, in terms of work replacement in the context of unprecedented waves of strikes and protection of private property and the so-called freedom to work. The ready availability of cheap revolvers gave strikebreakers easy access to weapons and the opportunity to use them, partly in self-defense and partly with the aim of intimidating unionized workers. Eventually, what fed the spread of violent gangs of strikebreakers was

\footnotetext{
${ }^{128}$ Salzburger Wacht, August 20, 1912, 1.

${ }^{129}$ Salzburger Wacht, February 10, 1911, 4.

${ }^{130}$ Berliner Morgenpost, October 4, 1910, 1-2.

${ }^{131}$ Berliner Morgenpost, October 4, 1910, 1-2.

${ }^{132}$ Vorwärts, February 13, 1914, 15.
} 
not only the employers' growing demand for work replacement and security during labor conflicts, but also the authorities' ambivalence in prosecuting antilabor violence. Violent actions, and even murder, carried out by armed strikebreakers were almost always considered cases of legitimate self-defense against the provocations and attacks by unionized workers.

According to the narrative of strike terrorism examined in the first section, strikebreakers were seen by government elites, especially in Germany, as part of the "loyal classes," and therefore deserving of special protection. ${ }^{133}$ Free labor unions and social democratic newspapers obviously played an active part in sensationalizing violent strikebreaking and used the term class justice to refer to the alleged protection of strikebreakers by state authorities. In 1907, for example, two strikebreakers killed a worker named Schödel during a pub brawl in the district of Wunsiedel in northeast Bavaria. Vorwärts described the murder as a state crime (Staatsverbrechen) because state authorities were protecting strikebreakers as "useful members of the community." 134 Episodes of violence, and especially the several unpunished murders, perpetrated by armed strikebreakers became emblematic cases of repression and legal discrimination against striking workers. The escalation of violence culminated with the killing of a striking worker by Paul Keiling, a German strikebreaking agent, in Bohemia in 1914.

Before the Keiling episode, six other cases of striking workers killed by armed strikebreakers in Imperial Germany went unpunished between 1906 and 1914. The first took place in 1906 outside the union motor vehicle factory near Nuremberg in Bavaria, where Ernst Thiel, a twenty-two-year-old strikebreaker, fired three times at one of the local trade union leaders, Melchior Fleischmann, who died two days later. ${ }^{135}$ In 1911, former police officer Brackhage fired his revolver, killing the dock worker Meierling during the Rhineland Transport Company strike in Duisburg. ${ }^{136}$ One year later, the prominent strikebreaker Joseph Ruppert killed a striking worker near Magdeburg, and in 1912 the German strikebreaker Otto Kaiser killed the Swiss worker Karl Wydler near Zurich. ${ }^{137}$ In 1913, a strikebreaker named Brandenburg stabbed striking worker Kühl with a bread knife in the port city of Stettin. ${ }^{138}$ There is also a very long list of workers seriously injured by armed strikebreakers in the same period. For example, violence escalated on both sides in Rohrbach an der Gölsen (Lower Austria) when a group of twenty strikebreakers coming home from the funeral of their employer's wife attacked two workers from another factory, bloodily beat them, and fired revolver shots. ${ }^{139}$ This violent incident took place in a context of heightened tensions between the two sides in the town after an apparent attack on a nonstriking worker a few days earlier. ${ }^{140}$

\footnotetext{
${ }^{133}$ For a more detailed discussion, see Amerigo Caruso, “Joining Forces against 'Strike Terrorism': The Public-Private Interplay in Policing Strikes in Imperial Germany, 1890-1914," European History Quarterly 49, no. 4 (2019): 597-624.

${ }^{134}$ Vorwärts, November 12, 1907, 6.

${ }^{135}$ Vorwärts, August 21,1906, 3; Arbeiter-Zeitung, August 26, 1906, 7.

${ }^{136}$ Vorwärts, October 6, 1911, 4.

${ }^{137}$ Gewerkschaftliche Rundschau für die Schweiz, January 5, 1912, 62; Vorwärts, November 31, 1912, 3.

${ }^{138}$ Vorwärts, June 7, 1913, 1.

${ }^{139}$ Arbeiter-Zeitung, June 4, 1911, 14.

${ }^{140}$ This is in any case how the factory owner justifies the behavior of his workers to the Union of Industrialists following the newspaper article in a letter dated June 13, 1911, ÖStA, AVA, MdI, Präs, K1995, sig. 20/9, no. 6505/11, June 22, 1911.
} 
The murder of print worker foreman Johann Solinger, on February 8, 1914, emerged as the most prominent case of antilabor violence in the prewar years. It rapidly became a transnational media sensation with several German, Austrian, and Swiss newspapers reporting extensively on it. What makes the episode so remarkable is that Solinger's murderer, Paul Keiling, was one of the most notorious German strikebreaking agents. In early January 1914, a few weeks before Solinger's murder, social democratic newspapers reported that Austrian employers were desperately searching for "willing print workers," and Keiling along with Katzmarek were involved in the recruitment and transport of German strikebreakers. ${ }^{141}$ Keiling's organization worked transnationally, not only in Prussia and Habsburg Austria but also in the German-speaking regions of the Swiss Confederation. A few days before Solinger's murder, Swiss newspapers reported that Keiling was active in Bern, supplying employers with willing workers. ${ }^{142}$ Other reports in the following months described the "Keiling bands" as a group of strikebreakers armed with revolvers and sticks. They brutally intimidated striking transportation workers in Braunschweig and openly proclaimed, "We strikebreakers can kill someone, nothing will happen to us."143

In the early morning of February 7, Keiling arrived in the small Bohemian city of Tetschen/Děćín during the print workers' strike. The report written by the Austrian gendarmerie after Solinger's murder provides a good overview of Keiling's activities in Tetschen:

Paul Kailig (sic), born in $1868, \ldots$ went with his companion to get breakfast when he was surrounded by 9 strikers, who had assembled the day before and among whom was Johann Solinger, master machine printer (father of 5 children). They reproached his behavior in a threatening manner. As Kailig feared something bad might happen to him, he took out his Browning loaded with 8 sharp cartridges and said: "The first one who approaches is dead!" Then Solinger charged at him and forced Kailig to retreat into the nearby kitchen. Kailig began to fear for his life and, unable to get away, fired a shot at Solinger, which seriously wounded him in the neck. Solinger died at $7 \mathrm{pm}$ from his wounds. That Solinger was prepared for a violent encounter is borne out by the fact that he had brought a $3 \times 40 \mathrm{~cm}$ rubber truncheon with him in his bag. Kailig was immediately arrested, admitted the crime and claimed to have acted in self-defense. Kailig was in possession of a valid weapon license issued by the police headquarters in Prague for a duration of 3 months. ${ }^{144}$

It is remarkable that Keiling was able to obtain a weapon license despite having a long list of prior convictions for theft, violence, robbery, and other crimes. Vorwärts journalists had already investigated Keiling's criminal record before Solinger's murder and uncovered seventeen convictions between 1895 and 1912. ${ }^{145}$ The newspaper reported the murder of Solinger for the first time on February 9, 1914 (on the front page!). It argued that foreign countries should erect a cordon sanitaire to keep out the "strikebreakers' plague" imported from Germany. Popular tabloids, such as the Berliner Volkszeitung and the Berliner Tageblatt also reported Solinger's murder. ${ }^{146}$ Articles in these newspapers and in comparable Austrian publications were fairly neutral and presented the story briefly without any comments. ${ }^{147}$ This was obviously not the case with Vorwärts and other social democratic

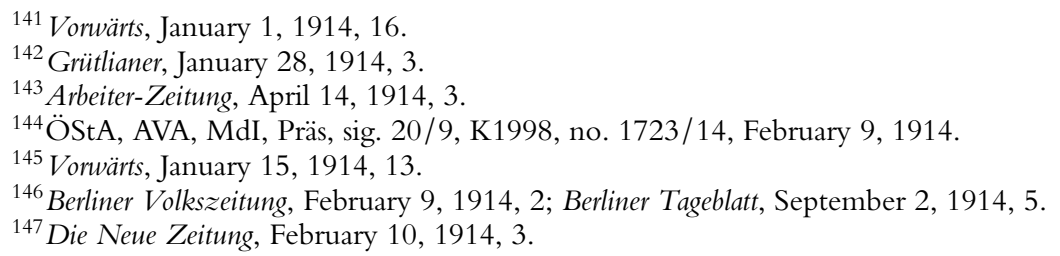


newspapers in Austria-Hungary and the Swiss Confederation, which reported almost daily on the murder. The entire front page of the Swiss socialist newspaper Grütlianer as well as the Austrian Arbeiter-Zeitung of February 12, 1914, was dedicated to the Solinger murder, perpetrated by "a seventeen-times convicted felon.", 148

According to the Arbeiter-Zeitung, Keiling worked as agent provocateur for the German police, ${ }^{149}$ and Vorwärts reported that even before the Solinger murder he proudly claimed to have police power (Polizeigewalt). ${ }^{150}$ Vorwärts further reported that during a strike in Berlin in 1913 Keiling also gave direct orders to the police: "Keiling, armed with a revolver and a knife, ordered the policemen: "Take out your sabers!"'151 Similar reports had appeared in the Austrian social democratic newspapers concerning Toni Meinel, another well-known agent of willing workers operating in Berlin, who reportedly presented himself as a "professional strikebreaker" and, according to the article, claimed: "I can do what I want, I am allowed in certain circumstances to shoot, I can even kill a man, I have the necessary police protection." 152 Along with the claims that they protected strikebreakers, the police were also accused of playing a role in the recruitment of willing workers. ${ }^{153}$ In his study of the Moabit riots, Thomas Lindenberger draws attention to the cooperation between the Berlin police and Hintze, which earned the latter the nickname "hero of Moabit" in the social democratic press. In his analysis of the riots, Lindenberger argues that the legitimacy of the state's monopoly of violence was undermined not only by police intervention but also because professional strikebreakers were tolerated and even encouraged. ${ }^{154}$

Several reports also focused on the doubtful morality of strikebreakers, who were described as frequenters of brothels, and who shocked the population with their aggressive, uncivilized behavior. ${ }^{155}$ In June 1906, Vorwärts reported from Cologne that armed strikebreakers from "semi-civilized regions," such as the Balkans and Italy, not only threatened striking workers but terrorized the entire city with violence and criminal activities. ${ }^{156}$ During a strike in Winterberg/Vimperk (Bohemia), the social democratic newspaper complained about the "scandalous" behavior of these men: "Every Sunday they take girls barely out of school from one bar to another, and they drink, fight, and brawl, even in the factory." 157 A similar complaint about strikebreakers imported from Germany during a strike in Nesselsdorf/Koprivnice (Moravia) referred to them as "a real clean company," always fighting and brawling, and who left the public baths "full of lice and foul." 158 In contrast, bourgeois newspapers, such as the Allgemeine Zeitung, stigmatized striking workers as violent alcoholics and published detailed reports to support the legitimacy of willing workers defending themselves from strike terrorism. ${ }^{159}$

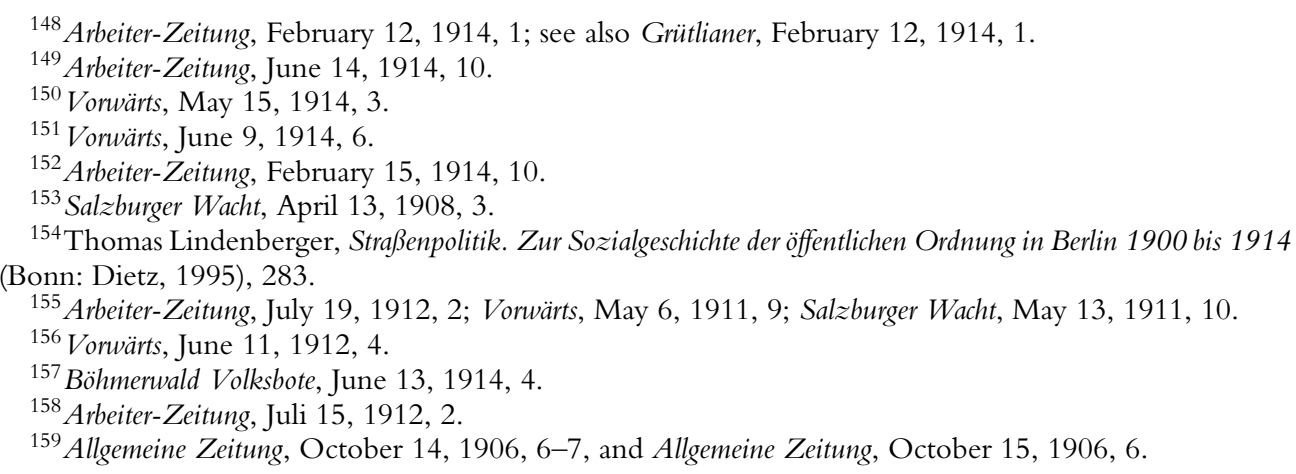




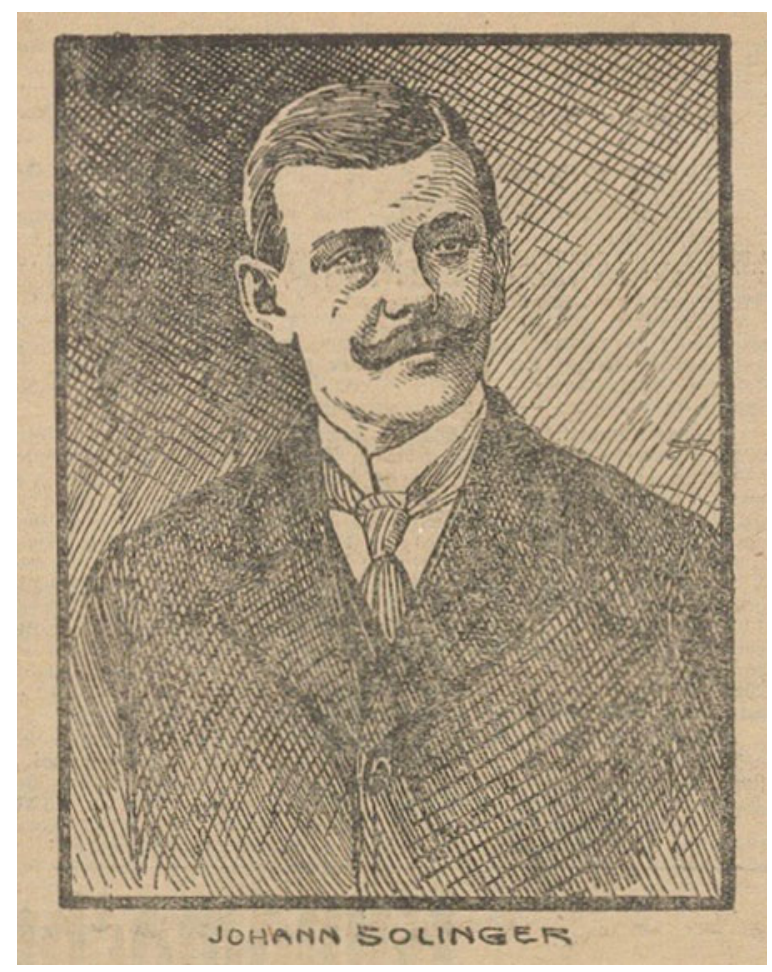

Fig. 2. "Im Lohnkampf erschossen" (Shot dead in a wage dispute) (Picture of Johann Solinger). Illustrierte Kronen-Zeitung, August 27, 1914, 11.

Although the narrative of class justice highlighted by the social democrats needs critical reassessment, the Prussian and Austrian authorities had a very permissive attitude toward strikebreakers defending themselves with weapons. ${ }^{160}$ The case of Keiling, who was sentenced to only eight months in prison, clearly demonstrated the quasi-impunity of violent strikebreakers, which was also evident in the aforementioned murders of organized workers by armed strikebreakers that were considered as self-defense. During the same Austrian book printers' strike of January 1914, a strikebreaking agent from Berlin shot at passers-by in the streets of Innsbruck. The police report, however, presented him as a victim of striking workers, who had been "attacked on the street" and fired his revolver to "scare his opponents."161

Bands of armed strikebreakers led by tolerated criminals, such as Keiling and Katzmarek, used private and extra-legal means to ensure the safety of the work-willing, and, more generally, protection of the bourgeois order, which was perceived as increasingly threatened. In the 1890s, employers, state authorities, and conservative parties tried without success to

\footnotetext{
${ }^{160}$ For a comprehensive analysis of the Kaiserreich's judicial system and the political debate on "class justice," see Uwe Wilhelm, Das Deutsche Kaiserreich und seine Justiz. Justizkritik, politische Strafrechtsprechung, Justizpolitik (Berlin: Duncker \& Humblot, 2010), 504-10.

${ }^{161}$ Phone report from the governor's office in Innsbruck, ÖStA, AVA, MdI, Präs, sig. 20/9, K1998, no. 1723/14, January 14, 1914. Compare with the report in the social democratic press: Vorarlberger Wacht, January $15,1914,3$.
} 
impose repressive counterstrike strategies, and therefore had recourse to private agents both for the recruitment of a cheap labor force and for security tasks. In this sense, the spread of violence and intimidation carried out by armed strikebreakers can be seen as a result of the expansion of the public sphere (through the democratizing pressures of parliaments and the press) that made legal discrimination and state-led repression of social movements more difficult. This radicalized social tensions and gave rise to a new field of violence based on privately organized coercion and its ambivalent relationship with the state.

\section{Conclusion}

By the outbreak of war, two discourses on strikes ran alongside each other in central European media: on the one hand depictions of replacement workers as hapless victims of violent strikers, and on the other hand unionized workers portrayed as living in fear of the rise of armed strikebreaking gangs. The concept of freedom was weaponized by both factions amid accusations of restricting the liberty to work on one side, and slave trading on the other. Both visions magnified and simplified the low-level violence between strikers and nonunion workers in the factories and streets of Germany and the Habsburg monarchy, but they also highlighted the growth of strikebreaking agents as important actors in labor conflicts. In the decade preceding the war, the activities of strikebreaking agents expanded considerably in Germany, Austria, and Switzerland, and their violent modus operandi had already had lethal consequences by 1914. Strikebreaking agents were part of the arsenal of measures to prevent strikes at a time when employers were becoming increasingly organized at the national level. Agents operated in a central European labor market with frequent border crossings and where a high level of dissymmetric information (heightened by language diversity) constituted an asset to them.

Armed groups of professional strikebreakers were responsible not merely for a quantitative increase in violence, but also, and more importantly, for a change in the structure of violence during strikes that highlights elements of continuity between the pre- and postwar years. The final years before the war saw, firstly, the emergence of new actors, often with criminal backgrounds that formed and led privately organized armed groups for antistrike purposes. ${ }^{162}$ Thus, the spread of privately organized coercion carried out by militarized citizens cannot be explained merely with the collapse of state authority and the anti-Bolshevik paranoia of the immediate postwar period (or with the brutalizing effects of the war). As this article has shown, this phenomenon has deeper roots, namely the radicalization of antisocialism and the privatization of antistrike activities in the prewar years. The second aspect that highlights continuity between the pre- and postwar years is the crucial role played by modern media in transmitting sensationalized violence. Furthermore, the "securitization" of the working class exacerbated social tensions and led to a radicalization of discursive violence. Thirdly, ideologically motivated violence became more widespread: though in the prewar years the boundary between ideological and purely economic motives was sometimes blurred, the ideological component was heightened after 1918. These three dimensions foreshadowed the escalation of violence-in terms of structure, not quantity - in the postwar years.

\footnotetext{
${ }^{162}$ On the link between the practices of armed civilians before the war to the paramilitary groups that emerged in 1918, see Claire Morelon, "Respectable Citizens: Civic Militias, Local Patriotism, and Social Order in Late Habsburg Austria (1890-1920),” Austrian History Yearbook 51 (2020): 193-219.
} 
Efforts to build strikebreaking units were formalized after the war. In Weimar Germany, the paramilitary Technical Emergency Corps (Technische Nothilfe) became a large organization aimed at replacing striking workers in industrial sectors considered to be of national importance. This governmental strike-breaking organization with thousands of volunteer members was placed under the control of the Ministry of the Interior by late 1919. It had originally formed "from below," however, as technical corps of the elite paramilitary unit led by Major Waldemar Pabst. ${ }^{163}$ In Austria, postwar militias such as the Heimwehr movement actively helped employers break strikes by recruiting and protecting strikebreakers. An Austrian Technische Nothilfe composed of volunteers was also created as part of the Heimwehr even though it did not develop as a state-mandated force as its German counterpart did. Its function was to replace striking workers and to keep communications and vital industries running in case of a political strike. The antistrike function of paramilitaries in Austria remained paramount throughout the 1920s. ${ }^{164}$

In the years leading up to the war, and before the rise of anti-Bolshevik paranoia, social democracy appeared as a major threat to the status quo, and strikes were at the heart of the battle lines. The transformation in the balance of power brought about by the growing importance of strikes was perceived as endangering society, private property, and the political process. The peril constituted by the rise of the workers' movement, and the possibility of a general strike, required employers to be better organized, including on a transnational scale. Attempts to achieve greater coordination were formalized with the creation of new institutions and networks in the interwar period, but the first steps in that direction had already been taken in the decade before 1914. ${ }^{165}$ This article has examined largely unexplored transnational connections both in labor activism and in the reactions to it. In doing so, it has shed new light on the vulnerability of central European empires in the prewar years, in which social tensions, labor migration, and conflicts related to contrasting notions of political modernization and national security played a major role.

\section{University of PADUA UNIVERSITY OF GREIFSWALD}

\footnotetext{
${ }^{163}$ In the following years, the Technical Emergency Corps became an emergency response unit that provided help after fires, storms, and other natural disasters. See Michael H. Kater, "Die Technische Nothilfe im Spannungsfeld von Arbeiterunruhen, Unternehmerinteressen und Parteipolitik," Vierteljahreshefte für Zeitgeschichte 27, no. 1 (1979): 30-78.

${ }^{164}$ John T. Lauridsen, Nazism and the Radical Right in Austria, 1918-1934 (Copenhagen: The Royal Library Museum Tusculanum Press, 2007), 119-20.

${ }^{165}$ Quinn Slobodian, Globalists: The End of Empire and the Birth of Neoliberalism (Cambridge, MA: Harvard University Press, 2018).
} 